IZA DP No. 129

The Employment, Unemployment and Unemployment Compensation Benefits of Immigrants

Barry R. Chiswick

Michael E. Hurst

March 2000 


\title{
The Employment, Unemployment and Unemployment Compensation Benefits of Immigrants
}

\author{
Barry R. Chiswick \\ University of Illinois at Chicago and IZA, Bonn \\ Michael E. Hurst \\ University of Illinois at Chicago
}

Discussion Paper No. 129

March 2000

IZA

P.O. Box 7240

D-53072 Bonn

Germany

Tel.: +49-228-3894-0

Fax: +49-228-3894-210

Email: iza@iza.org

This Discussion Paper is issued within the framework of IZA's research areas Mobility and Flexibility of Labor Markets and The Welfare State and Labor Markets. Any opinions expressed here are those of the author(s) and not those of the institute. Research disseminated by IZA may include views on policy, but the institute itself takes no institutional policy positions.

The Institute for the Study of Labor (IZA) in Bonn is a local and virtual international research center and a place of communication between science, politics and business. IZA is an independent, nonprofit limited liability company (Gesellschaft mit beschränkter Haftung) supported by the Deutsche Post AG. The center is associated with the University of Bonn and offers a stimulating research environment through its research networks, research support, and visitors and doctoral programs. IZA engages in (i) original and internationally competitive research in all fields of labor economics, (ii) development of policy concepts, and (iii) dissemination of research results and concepts to the interested public. The current research program deals with (1) mobility and flexibility of labor markets, (2) internationalization of labor markets and European integration, (3) the welfare state and labor markets, (4) labor markets in transition, (5) the future of work, (6) project evaluation and (7) general labor economics.

IZA Discussion Papers often represent preliminary work and are circulated to encourage discussion. Citation of such a paper should account for its provisional character. 
IZA Discussion Paper No. 129

March 2000

\section{ABSTRACT \\ The Employment, Unemployment and Unemployment Compensation Benefits of Immigrants}

This report analyzes the employment and unemployment experiences of adult foreign-born men, both among themselves and in comparison with the native born. The empirical analysis uses microdata from the 1990 Census of Population. Three dependent variables are analyzed, weeks worked (employment) in 1989, unemployment status in the reference week in 1990, and a proxy measure of unemployment compensation benefits received in 1989 . The theoretical model focuses on the job search behavior of the foreign born within the context of an immigrant adjustment model based on the imperfect transferability of skills and labor market information acquired prior to immigration. In particular, the model focuses on the effects on employment and unemployment of schooling, labor market experience, marital status and the agricultural sector, in addition to English language fluency and country of origin. The hypotheses developed from the model are found to be consistent with the data. Employment is significantly lower, and unemployment is significantly higher, among the foreign born in the U.S. for three or fewer years, but then reaches a level after which there is little variation by duration of residence. Unemployment problems associated with immigrants appear to be short-term transitional adjustments.

JEL Classification: J 61

Keywords: Adjustment process, language fluency, country of origin

Barry R. Chiswick

Department of Economics

University of Illinois at Chicago

601 South Morgan Street

Chicago, IL 60607-7121

USA

Tel.: +1-312 996-2684

Fax: +1-312 996-3344

Email: brchis@uic.edu 


\section{Introduction}

In the past two decades there has been renewed interest in the economic adjustment of immigrants and the impact of immigrants on the labor market and economy of the United States. This has resulted from an increase in the scale of immigration, from 252,000 per year in the 1950 's to over 734,000 per year in the 1980 s, and to over 900,000 per year in the 1990's. The foreign born have increased to over 10 percent of the labor force. ${ }^{1}$

The analysis of immigrant economic adjustment has focused primarily on hourly or weekly earnings and to a lesser extent on occupational mobility. These are important issues for understanding the economic well-being of immigrants and for determining the progress of their economic assimilation. Another important dimension, however, of the economic adjustment of immigrants is the degree of their employment, unemployment and receipt of unemployment compensation benefits. The employment and unemployment experiences of immigrants, and their receipt of unemployment compensation benefits, are important for analyzing the annual income of immigrants, and their impact in the labor market, as well as for societal interests in unemployment per se. 
During the Depression of the 1930s and in the early post-war years when there was a fear of the return of the Great Depression, there was interest in the unemployment of immigrants. Even then there were few studies, with Fields (1935) and Rubin (1947) being two notable exceptions. The more recent resurgence in immigration and the implications for unemployment have resulted in little additional research on the topic. There have, however, been two studies analyzing the unemployment of the foreign born, using micro-data from the 1970 Census of Population and the 1976 Survey of Income and Education (SIE) in Chiswick (1982) and the microdata from a pooling of several samples from the Current Population Survey in Chiswick, Cohen and Zach (1997).

As it is likely that immigration will continue at the current levels, the share of immigrants in the labor market, currently at over 10 percent, will continue to grow. Moreover, immigrants are not uniformly distributed across the population, but rather tend to be concentrated in a few states, most notably California, Texas, Florida, New York, New Jersey and Illinois. This can, in principle, place a disproportionate impact of immigrants on the unemployment compensation programs of selected states.

This paper analyzes the employment and unemployment experiences of adult male immigrants using micro-data from the 1990 Census of Population. It also develops an algorithm for analyzing the receipt of unemployment compensation benefits by the 
foreign born. Section II develops the model or conceptual framework used for the analysis. The data to be analyzed are presented in section III. Section IV analyzes in turn the three dependent variables, weeks worked in 1989 (employment), unemployment in the reference week in 1990 (the last week in March 1990), and a proxy for "unemployment compensation" benefits received in 1989. The analysis will focus on immigrant related variables, such as nativity, duration in the United States, citizenship status, whether or not fluent in English, and specific country of birth.

\section{The Models: Theoretical and Empirical ${ }^{2}$}

This section develops the theoretical framework for analyzing immigrant employment and unemployment. It examines the job search behavior of immigrants in comparison with the native born, and among the foreign born by duration in the U.S., country of origin and other characteristics. Because of the less than perfect transferability of skills and labor market information, immigrants are at a disadvantage when they enter the United States labor market. In time they adjust, in part through investments that modify skills, but often only after voluntary job changes and unemployment. Because they have fewer skills specific to their employer, immigrants are also more vulnerable to layoffs due to cyclical, seasonal, 
and transitory changes in economic activity. They therefore also experience more involuntary job turnover and unemployment.

The specification of the variables in the estimating equation that are specific to immigrants is then developed. Employment is shown analytically to be related to the person's skill level (including schooling and labor market experience) and demographic characteristics. Among the foreign born, other potentially relevant variables are: the duration of residence in the United States, the country of origin, whether the immigrant is a naturalized citizen, and English language skills.

\section{A. Immigrants and Job Search}

Immigrants entering a labor market have similarities to native-born persons who are new entrants or reentrants to the labor market. In general, immigrants do not have a specific job waiting for them. Engaging in job search when ones does not have a job constitutes unemployment. It has been shown that much of the excess unemployment of youths and adult women in the United States in comparison with adult men can be attributed to their being recent entrants or reentrants to the labor market. The same is likely to be true for new immigrants.

Because skills and knowledge do not transfer perfectly from country to country, immigrants at first are less productive than the native born in the U.S. labor market. This implies a lower distribution of wage offers. Because immigrants have less 
information about the labor market, they have greater uncertainty about high-paying jobs that are available. This results in a greater incentive to invest resources in the job search process and in training to increase the transferability of their skills. If the wealth to finance investments in job search were the same for the native born and the foreign born, there would be a greater actual investment of resources by the foreign born. One such resource is "own-time," which is often more profitably employed when a person is not working. It is the use of own-time in the job search process that generates unemployment or less than full-year employment.

Immigrants initially have an incentive to make greater investments in skill and information relating to the U.S. labor market but not in training that is useful only for the current employer (firm-specific training). Part of the early investment is learning about the labor market, which is often done best by experiencing a variety of jobs. Investing in firm-specific training, however, raises the cost of an experimental job change. Yet the smaller the investment in firm-specific training, the lower the incentive for immigrants to remain in their present employment and hence the greater the likelihood of job quits for any reason, not solely to experience a different employer or workplace.

As their residence lengthens, immigrants acquire more skills and knowledge relevant to the U.S. labor market, in part through modification, adaptation, or 
credentialing of preexisting skills. Some of this arises from conscious investment decisions and some from everyday experience. As skills relevant to the United States increase, upward occupational mobility becomes more feasible and job changes often result.

Not only do new immigrants have less information about the U.S. labor market, but also U.S. employers are less able to judge the skills of new immigrants in comparison with the native born. As a result, lower wage offers and more hiring errors ( and hence more discharges) will be made, and employers will be more reluctant to finance investments in firm-specific training for new immigrants. In addition, the anticipation of upward occupational mobility by immigrants would further discourage the financing of firm-specific investments by employers, particularly by employers who cannot or do not expect to internalize this upward mobility. A lower investment made by a firm for a new immigrant's training diminishes the firm's commitment to the worker, and many more layoffs can be expected because of seasonal, cyclical, or transitory changes in business conditions.

Hence, both the new immigrants and their employers anticipate greater turnover during the period of investments by the immigrants in country-specific skills (including learning simply by living in the country) and smaller investments by both in firm-specific training. Indeed, the anticipation of greater turnover from quits, 
layoffs, and discharges is in part a self-fulfilling prophecy, since greater job turnover discourages firm-specific training, thereby encouraging turnover.

Greater job turnover among recent immigrants would not result in greater unemployment if the immigrants immediately take other jobs or permanently drop out of the labor force. Although these outcomes do occur, there is often a period of job search without employment.

Recent immigrants may have greater difficulty financing their job search than native-born men, partly offsetting the factors considered above. Unemployment compensation is available for workers who lose a job in covered employment as a result of a layoff, but the benefits are less likely and the waiting period is longer if the separation is a discharge or if it is voluntary (a quit). All state programs have a work history requirement that typically links benefits to employment in a covered job in the first four of the five calendar quarters before the onset of unemployment. Since work credits are not earned for preimmigration employment, recent immigrants are generally not eligible for unemployment compensation benefits unless they have been employed in a job (or jobs) covered by the program for at least a year after entering the country.

This discussion implies that recent immigrants would tend to experience more spells of unemployment, both voluntary and involuntary, than would native-born 
workers, other things being the same. It also implies that unemployment among immigrants, particularly recent immigrants, will be more sensitive to seasonal, cyclical, and random fluctuations in business conditions than unemployment among the native born. As their skills and labor market information relevant to the U.S. improve, they will learn more efficient job search methods, and can be expected to approximate the job search behavior and unemployment experience of native-born workers. The speed at which this occurs and the number of years until there is employment (weeks worked) and unemployment parity with the native born are, of course, empirical questions.

It is conceptually useful to distinguish economic migrants, persons who move primarily for narrowly defined labor market reasons, from refugees, persons whose decisions to migrate are influenced by non-labor market considerations such as political ideology or identity, social class, race, or ethnic origin. Economic migrants are more likely to have anticipated and prepared for their move. Economic migration streams will include a larger proportion of individuals who are adept at adjusting to new situations, that is, they are likely to be more highly "favorably selected" than refugees. Thus, economic migrants are expected to adjust more easily to the U.S. labor market. Moreover, in recent years refugees are eligible for transitional Federal income support assistance that is not available to other immigrants. Refugees are 
therefore expected to have higher unemployment or lower employment during their first few years in the United States, and their employment during the early period is expected to be more cyclically sensitive.

\section{B. Modeling the Immigrant Experience}

The estimating equation is developed for a microeconomic model, that is, a model in which the unit of observation is an individual. This discussion shall be in terms of employment (weeks worked) because this is the dependent variable used in much of the empirical analysis. The same arguments generally apply, however, to unemployment, but with the opposite sign. The discussion of the basic variables relevant to the native born and the foreign born is presented first, and then the variables that are unique to the foreign born are developed. Figure 1 presents a listing of the dependent and explanatory variables used in the analysis, as well as their codes and the hypothesized partial effects of the explanatory variables on employment.

\section{FIGURE 1 ABOUT HERE}

In the microeconomic model of employment the person's skills and demographic characteristics are key explanatory variables. The extent of employment tends to be greater among those who have a larger stock of skills relevant to the labor market. Not only do higher wages mean a higher cost of not working, but also there is an 
apparent positive association between investments in formal training (schooling) and informal or postschool training, including firm-specific training. Greater investments in firm-specific training are associated with lower turnover because the training is not productive in alternative employments and the investment is shared by the worker and employer (Becker, 1964).

These effects imply a greater number of weeks worked in a year for those with more years of formal schooling. Years of labor market experience or on-the-job training are also associated with lower quit and layoff rates. Thus employment increases with labor market experience, although the initial sharp rise in employment with years of labor market experience tapers off. The maximum potential labor market experience is estimated as age minus schooling minus five years. This is a close approximation of actual labor market experience for adult men, and it is entered as a quadratic variable.

Since the extent of employment varies systematically by certain demographic characteristics, it is important to control statistically for these effects. Employment tends to be greater among married men, apparently because marriage is associated with increased specialization in labor market activities by men. Marital status is held constant by a dichotomous variable that takes the value of zero for men who are married (spouse present) and unity for men in other marital statuses. 
Additional control variables include industry/occupation and place of residence. Because of its unique characteristics, including a high degree of seasonality, it is useful to enter a variable for the agricultural sector. This is done through a dichotomous variable that is unity for workers reporting their industry and occupation is in agriculture. Region of residence is taken into account through variables for size of place and for the southern states.

Is there an effect of nativity on the extent of employment after controlling for differences in skill (schooling and total labor market experience) and for demographic characteristics (marital status and place of residence)? Although this question could be answered by including a dichotomous variable for foreign birth, by itself that variable is inadequate and can be misleading. There are several dimensions of being foreign born that may be relevant for employment, including duration of residence in the United States, country of origin, English language skills and citizenship.

The effects of duration of residence (or year of immigration) on employment have been discussed. The variable is entered into the analysis as a set of dichotomous explanatory variables, one for each of the year-of-immigration intervals provided in the census data. The procedure permits a fuller examination of potential nonlinearities in the differential effect on weeks worked of labor market experience 
in the United States compared with labor market experience in the country of origin. Controlling for duration of U.S. residence, the coefficient of the variable for total labor market experience measures the impact of pre-immigration labor market experience on employment. Controlling for total experience, the coefficient of the variable for duration of U.S. residence measures the differential impact on employment of experience in the United States.

Fluency in the destination language is a form of human capital that has been shown to be productive in the labor market through enhancing earnings (Chiswick and Miller, 1995). There has been less research on the effect of language skills on employment. The more fluent are likely to be more efficient in finding a better job match, thereby reducing the extent of job turnover (spells of unemployment) and shortening the duration of job search. Then English language fluency among the foreign born would be associated with a greater number of weeks worked in the year. Labor market adjustments are likely to be easier for immigrants from countries that are similar to the United States in language, occupational requirements, and labor market structure. Since refugees are less likely to have planned for the move, their skills are not as transferable. They would be expected to have greater difficulty in finding a job and to be more likely to invest in training programs to increase the transferability of their skills. The effects will be greatest during the first few years 
in the United States. Refugees may also be less favorably selected for adjusting to the destination labor market and may therefore have higher quit and layoff rates and fewer weeks worked. Dichotomous variables for country of origin are included in the analysis to test for these effects. With the British Isles as the benchmark, it is hypothesized that the partial effects on weeks worked of the variables for nonEnglish-speaking countries are negative, and that the negative effects are most pronounced for the country category with the largest proportion of recent refugees, those born in the USSR.

There are various legal barriers to the employment of aliens--foreign-born persons who are not naturalized citizens. Owing to a Presidential Executive Order, the employment of aliens is severely limited in the Federal Civil Service. Some state occupational licensing laws require applicants to be citizens, or in the process of acquiring citizenship, to receive a license. The 1964 Civil Rights Act and subsequent amendments and administrative regulations bar discrimination in the private sector on the basis of national origin, race, and religion, but did not bar discrimination against aliens. In 1973 the Supreme Court confirmed this interpretation in the Farrah Manufacturing Co. case. The legal climate changed with the passage of the 1986 Immigration Reform and Control Act which made it illegal for private sector employers to discriminate in employment against lawful permanent resident aliens. 
In spite of the change in the law, some employers may engage in discriminatory behavior. If so, these policies narrow the employment opportunities of aliens. However, the number of employers, including other aliens, who do not discriminate may be sufficiently large so that there is no adverse effect on employment.

The discrimination hypothesis suggests that naturalized citizens would work more weeks per year than otherwise similar aliens. To the extent that those with an easier adjustment in the U.S. labor market are also more likely to become citizens, there would also be a positive observed relationship between employment and citizenship, even if there were no discrimination against aliens. Both hypotheses predict a positive partial correlation between employment and citizenship, and their separate effects cannot be identified. A citizenship variable is included in the analysis, to test whether citizenship has a favorable effect on employment.

Three dependent variables from the 1990 Census of Population are analyzed in this study: weeks worked in the reference year (1989), unemployment status in the reference week at the end of March 1990 (i.e., the week prior to completing the census form) and "unemployment compensation" benefits in 1989. Although much of the public policy discussion and media attention centers on the unemployment of immigrants, the empirical analysis in this study also focuses on employment, as measured by the number of weeks worked in a year, rather than relying on 
unemployment status in the reference week. Among adult noninstitutionalized men (ages twenty-five to sixty-four), labor force participation rates in any week are very high, about 95 percent. It is even higher among those who are labor force participants at any time during the year. For adult men, more than for any other group, employment and unemployment are virtual complements.

An important advantage of using the weeks worked data in addition to the unemployment data in the 1990 Census as the dependent variable is that weeks worked is based on 52 weekly experiences for each observation, whereas unemployment is based on a one-week experience. The difference in the dependent variable is not expected to result in substantive differences in findings, but because it is based on 52 one-week observations the power of the analysis is expected to be greater in the weeks-worked analysis. Moreover, the data on unemployment in the census reference week are subject to patterns of seasonality that may vary in a systematic manner across the groups or explanatory variables under study. A disadvantage of the weeks worked data, however, is that they are subject to greater recall error.

There are no direct data on unemployment compensation benefits in the 1990 Census of Population. The last question on the person's income asks the respondent "32. Income in $1989 \ldots$ h. Any other sources of income received regularly such as 
Veterans (VA) payments, unemployment compensation, child support or alimony. Do Not include lump-sum payments, such as money from an inheritance or the sale of a home." It provides for the respondent to indicate the dollar amount (Census, 1993, p. E-15). The more detailed instructions indicate: "All other Income-Includes unemployment compensation, Veterans Administration payments, alimony and child support, contributions received periodically from person not living in the household, military family allotments, net gambling winnings and other kinds of periodic (cash) income other than earnings." (Census, 1993, p. B-17). Previous questions had asked the respondent to report wage, salary, self-employment (farm and non-farm), interest, dividend, net rental, social security, public assistance and retirement and disability income. Under the assumptions that adult males are not likely to be recipients of alimony or child support payments, and that the reporting of net gambling winnings is random with respect to the variables of interest, this income category (INCOME8) is likely to reflect unemployment compensation benefits when the sample is limited to adult (age 25 to 64 years) men who are not veterans, are not disabled, are not currently in the military, and are not currently enrolled in school. See Appendix A, which is available upon request from the authors, for a fuller discussion of this procedure. 


\section{The Statistical Analysis}

This section presents the empirical analyses for adult foreign-born men, both among themselves and in comparison with the native born. It begins with the determinants of weeks worked in 1989 among those who worked at least one week and had non-zero earnings in 1989. This is followed by the analysis of unemployment among those in the labor force in the reference week. The final subsection analyzes the "unemployment compensation" income received in 1989.

Table 1 reports the means and standard deviations of the dependent and the explanatory variables, for the foreign born and the native born. The foreign born worked 1.6 fewer weeks than the native born ( 45.8 weeks compared to 47.4 weeks) or 3 percent fewer weeks and had a higher rate of unemployment (6.2 percent compared to 4.8 percent) (Table 1). The lower employment and higher unemployment rate of the foreign born may, in part, be due to their lower level of schooling, 12.0 years in contrast to 13.5 years. It may also be due to their recency of arrival, 40 percent have been in the U.S. for 10 or fewer years at the time of the Census. Among the foreign born, only 41 percent were naturalized citizens, while only 52 percent spoke only English at home or, if they spoke another language, spoke English very well. The largest single source country was Mexico (23 percent

of the foreign born), with nearly another quarter of the immigrants coming from each 
of the other three major regions, Europe/Canada, Asia, and other parts of Latin America.

\section{TABLE 1 ABOUT HERE}

\section{A) Weeks Worked}

Table 2 reports the OLS regression analysis for weeks worked in 1989 for the native born (column 1) and the pooled sample of the native and foreign born (columns 2 to 4). Regressions limited to the foreign born are reported in Table 3.

\section{TABLE 2 ABOUT HERE}

\section{TABLE 3 ABOUT HERE}

Although the simple difference in employment was 1.6 fewer weeks worked by the foreign born, after controlling for schooling, experience, marital status, region of residence, and whether employed in agriculture, this declines by 60 percent to 1.0 fewer weeks worked in the non-farm sector and 2.3 fewer weeks among the foreign born in agriculture (Table 2, column 2). The pattern of fewer weeks worked among the foreign born is not invariant with duration in the United States. Other things the same, the foreign born in the United States for 3 or fewer years worked 5.9 fewer weeks, but this drops rapidly with duration to 1.3 fewer weeks for those in the U.S. 4 to 5 years, 1.2 fewer weeks for 6 to .8 years, 1.0 fewer weeks for 9 to 10 years, 0.6 fewer weeks for 11 to 15 years, and only 0.22 fewer weeks for the 16 to 20 year 
group (Table 2, column 3). For longer durations there is no significant difference from the native born.

Could this steep increase in weeks worked with duration of residence be merely a cohort effect, with recent cohorts being less adept at finding and retaining employment? Analyses performed elsewhere suggest that there in no cohort effect. Data from the 1970 Census of Population, the 1976 Survey of Income and Education and pooled samples from the Current Population Survey (four samples from 1979 to 1988) also find relatively low employment in the first few years and a steep increase in weeks worked with duration of residence (Chiswick 1982, Chiswick, Cohen and Zach, 1997). In particular, among adult white men in the 1970 Census, the foreign born in the U.S. up to 5 years worked 2.9 fewer weeks than the native born, and those in the U.S. 6 to 10 years worked 1.1 fewer weeks, in contrast to the 4.1 weeks and 1.4 weeks, respectively, for white men in the 1990 Census. Yet the recent immigrant cohort that experienced low employment in the 1970 Census or the 1976 SIE did not differ in their weeks worked from the native born in the 1990 Census. Thus, the increase in weeks worked with duration observed in the 1990 Census appears to be a robust finding describing the immigrant adjustment process, that is, reflecting the acquisition of U.S.-specific skills and information (both formal and informal) with an increase in duration in the U.S. 
This interpretation is strengthened when variables are added to the equation for naturalized citizens and fluency in English among the foreign born, as in Table 2, column 4. Immigrants who are naturalized citizens and who have fluency in English work more weeks in the year, 0.7 weeks and 0.5 weeks, respectively, and these differences are highly significant. Indeed, when these variables are held constant, the coefficients on the duration variables become more negative, reflecting fewer weeks of employment among aliens who are not fluent in English.

In Table 3 the analysis is limited to the foreign born. It is instructive that the signs of the human capital and demographic variables are the same and all are highly significant in the separate equations for the native born and foreign born (compare Table 2, column 1 and Table 3, column 2). Among the foreign born an extra year of schooling increases weeks worked by about 0.25 weeks per year, while an extra year of (pre-immigration) labor market experiences raises it by about 0.1 weeks per year when evaluated at 10 years. Marriage has a large effect; although the exact causal relationship may be ambiguous, married foreign-born men work 2.5 weeks more than otherwise similar men who are not married.

It should be noted that years of schooling and years of labor market experience (when duration in the U.S. is held constant) have smaller partial effects for the foreign born than the native born. Similar patterns were found in analyses of 
immigrant earnings (Chiswick, 1978, 1979) and were attributable to the less-thanperfect transferability of the skills acquired in the origin rather than in the U.S. A similar interpretation could apply here as well.

There are sharp differences in the effects of place of residence and industry. Rural and southern residence and the agricultural sector have highly significant effects on immigrant employment (Table 3, column 2). Living in the South lowers weeks worked by 0.3 weeks, while working in a non-agricultural sector in a rural area raises employment by 0.3 weeks compared to an urban area. Employment in the agricultural sector (industry and occupation) lowers the number of weeks worked by 4.1. This is in contrast with the native born for whom there is no employment difference between the rural nonfarm sector and urban areas and a slightly smaller (although statistically significant) number of weeks worked in the South (Table 2, column 1 , coefficient $=-0.07, \mathrm{t}=-2.3$ ). And, among the native born the agricultural sector effect on employment is only 1.5 fewer weeks, much smaller than the 4.1 fewer weeks among the foreign born. Thus, agricultural employment is associated with many fewer weeks worked in the year among the foreign born, who are primarily hired farm laborers, in contrast to the native born in this sector among whom there is a high rate of self-employment or family-member employment. ${ }^{3}$ 
When the analysis among the foreign born considers the effects of immigrantrelated variables robust patterns emerge. Using the 1975-1979 group (11 to 15 years) as the benchmark, weeks worked increases with duration in the United States. The most dramatic change occurs in the first decade when employment increases from 5.4 fewer weeks than the benchmark for the 1987-90 cohort to 1.5 fewer weeks for the 1985-86 cohort, to 0.8 fewer weeks for the $1982-84$ cohort, and to 0.3 fewer weeks for the 1980-81 cohort, where all of these differences are statistically different from zero (Table 3, column 2). Immigrants in the U.S. longer than the benchmark generally work more weeks in the year.

When the data are limited to the foreign born, naturalized citizens work 0.9 weeks more than aliens, and those who speak only English or speak it very well work 0.9 more weeks ( 0.75 weeks when county of origin is held constant) than those who are not fluent.

Other variables the same, with the British Isles as the benchmark, immigrants from all countries of origin work fewer weeks. The differences are small for most European countries but exceed 2.0 weeks per year for three large groups, immigrants from the USSR (-2.8 weeks), Korea (-2.1 weeks), and Mexico (-2.1), as well as for two small heterogenous groups, Other Africa (-2.0 weeks), and Other Countries 
(-2.3 weeks). The explanations for these patterns by country of origin may well differ, such as refugee effects for those from the USSR, and seasonal employment and sojourner job turnover among those from Mexico. ${ }^{4}$

\section{B) Unemployment}

The statistical analysis of unemployment among those in the labor force in the reference week in March 1990 is reported in Table 4. Among both the foreign born and native born, those with more schooling and who are married have lower rates of

unemployment. Among the native born more labor market experience is associated with lower unemployment, but more pre-immigration experience has no effect on unemployment among the foreign born. Those living in the South and those in rural areas who are not in the agricultural sector have lower rates of unemployment among both the native born and foreign born.

\section{TABLE 4 ABOUT HERE}

A divergence by nativity appears in the data for the effect on unemployment of being in an agricultural occupation and industry. The unemployment rate among the native born is lower in agriculture than in other industrial sectors by 0.7 percentage points $(\mathrm{t}=-3.65)$, while among the foreign born it is higher by 3.0 percentage points $(t=12.25)$. The nature of agricultural employment is very different among the native born, where self-employment and family employment dominate, than among the 
predominantly hired farm labor among the foreign born, and this has its effects on the patterns of unemployment.

Other variables the same, the foreign born have a lower unemployment rate than the native born, by 0.3 percentage points $(t=-3.42)$ in the non-agricultural sector but a higher unemployment rate (by 0.8 percentage points) in the agricultural sector (Table 4, column 2).

In the regression equations limited to the foreign born, compared with the benchmark, the 1975-79 cohort, the unemployment rate is higher among the most recent immigrants, the $1987-90$ cohort (3.0 percentage points higher, $t$-ratio $=15.8$ ), but the rate for the benchmark does not differ significantly from the rate for other immigrants who arrived in the 1980's (Table 4, column 5). Although earlier cohorts (1950's to 1974) have significantly higher unemployment rates, the differences are very small, less than 0.8 percentage point. Other variables being the same, within the first 3 years the unemployment rate reaches a plateau, and thereafter does not vary much with duration of residence.

Citizenship and English language skills are both associated with lower levels of unemployment, about one-percentage point each, and the effects are highly significant. 
Country-of-origin differences in the unemployment rate can be substantial. Most notable are immigrants from the USSR with an unemployment rate 8.1 percentage points $(\mathrm{t}-\mathrm{ratio}=15.9)$ greater than the benchmark, the British Isles. Other very high unemployment rate groups include immigrants from the English-speaking West Indies (4.3 percentage points higher), Other Latin America, Africa, and Indochina (all over 2 percentage points higher), whereas the Japanese report 3.4 percentage points lower unemployment rates. The extraordinarily high unemployment rates among Soviet immigrants is a temporary phenomenon--the gap diminishes with duration of residence. ${ }^{5}$

The unemployment rate of immigrants from Mexico is only 1.7 percentage points higher than that of British Isles immigrants. Their disadvantage in terms of weeks worked is much greater than their disadvantage in terms of unemployment rates. This may arise from a greater propensity for seasonal employment and sojourner migration, that is, alternating periods of employment in the U.S. with spells in Mexico as a substitute for unemployment in the United States.

In Table 5 the unemployment regressions are recomputed using logistic regression analysis. The observed patterns are the same as in the OLS analysis. Unemployment rates decrease with education and are lower among those who are married and are 
living in the south. The agricultural sector is associated with lower unemployment among the native born, but higher unemployment among the foreign born.

\section{TABLE 5 ABOUT HERE}

In the non-agricultural sector the foreign born have a lower unemployment rate than the native born, although in the agricultural sector the foreign born have a higher unemployment rate in the OLS analysis but not in the Logit analysis. (Tables 4 or 5, column 2). Among the foreign born, unemployment rates are lower for naturalized citizens and those more fluent in English (Tables 4 or 5, columns 5). Unemployment rates are particularly high among immigrants in the U.S. for three or fewer years (Tables 4 or 5, column 5). Immigrants from the USSR show particularly high unemployment rates, while those from Japan have the lowest rates. Mexican immigrants also exhibit higher unemployment rates, other things being the same, than British immigrants. This may be due to differences in seasonal patterns of employment and unemployment, and may be related to a higher propensity for returning to and from origin among Mexican.

\section{C) "Unemployment Compensation" Benefits}

The analyses reported in Table 6 and Table 7, and in Appendix B which is available upon request from the authors, are concerned with the measure of unemployment compensation benefits. As indicated in Appendix A, the census 
variable for "other income," INCOME8, can be used as a proxy measure of unemployment compensation benefits for groups that do not receive other income transfers on a recurring basis. That is, it is a proxy for unemployment compensation benefits under the assumption that few men receive Aid to Families with Dependent Children (AFDC) or alimony income, and by excluding from the sample those who are veterans, in the Armed Forces, disabled or enrolled in school as they may be receiving recurring income on this basis (See Appendix A). ${ }^{6}$

The Tobit regression analysis for the receipt of unemployment compensation benefits, as measured in this study, is reported in Table 6 for the native born and the pooled analysis. The dollar amount of this income can be decomposed into the probability of receiving any income from this source and the amount received by recipients, and among recipients the number of weeks benefits are received and the weekly benefit amount. This decomposition is reported schematically in Table 7, with the detailed regression analyses presented in Appendix B.

\section{TABLE 6 ABOUT HERE}

\section{TABLE 7 ABOUT HERE}

Among both the foreign born and the native born, the measure of unemployment compensation benefits and the probability of receiving a benefit decreases with higher levels of schooling, although the amount of the benefit for recipients rises 
with the level of schooling, reflecting higher wage rates. Total benefits are not related to labor market experience among the foreign born once duration of residence in the U.S. is taken into account, although it has a positive effect among the native born. Among recipients, however, benefits increase with experience again reflecting their higher wage rate. Whereas those who are in agriculture receive higher total benefits and have a higher probability of receiving a benefit among the foreign born, the opposite is found among the native born, again reflecting the lower rate of eligibility due to a higher rate of self-employment.

Other things the same, the foreign born received significantly lower unemployment compensation benefits than the native born. The most recent cohort, 1987-90, received particularly low benefits and the difference is highly statistically significant. The low benefits in spite of the lower level of weeks worked and higher unemployment rate may well be due, in part, to the prior work requirements to qualify for benefits, and the ineligibility for benefits or fear of applying among illegal aliens. There is a tendency for the benefit gap between the foreign born and the native born to diminish with duration of residence, that is, benefits increase with duration of residence.

The analyses in Table 7 and Appendix B indicate that although the foreign born receive significantly less in the measure of unemployment benefits analyzed here, 
this is due to a lower probability of receiving any benefits. Among recipients, the foreign born receive either the same or larger total benefits and a higher weekly benefit.

The analysis of the effects of duration of residence on unemployment compensation benefits indicates that the foreign born receive lower total benefits because of a lower probability of receiving any benefits. This period of significantly lower total benefits than the native born extends for about 20 years, although the magnitude of the effect diminishes with duration. Indeed, there is little difference between the foreign born and the native born, other variables the same, for the total benefits received by recipients or for the weekly benefits received by recipients.

The lower probability of receiving benefits among the foreign born in the first few years in the United States in spite of their higher unemployment rate may be related to the requirement of work in covered employment. That is, the most recent of immigrants may have been working in the U.S. too short a period of time to satisfy program eligibility requirements. The persistence of the lower probability of receiving benefits for up to 20 years requires other explanations. Other variables the same, citizenship and English language skills have a negative effect on benefits received and the probability of receiving benefits, but not on the magnitude of benefits among recipients. 


\section{Summary and Conclusion}

This report has analyzed the employment and unemployment experiences of adult foreign-born men, both among themselves and in comparison with the native born. It was based on an econometric analysis of data from the 1990 Census of Population, Public Use Microdata Sample, 1 percent and 5 percent samples. Three dependent variables are analyzed: the number of weeks worked in 1989, unemployment status in the reference week in 1990, and a proxy measure of unemployment compensation benefits received in 1989 .

The theoretical model focuses on the job search behavior of the foreign born in comparison with the native born, and among the foreign born by duration in the U.S., country of origin, naturalization, English language fluency, and other characteristics. The job search model applied to immigrants emphasizes the less than perfect transferability from their origin to the destination labor market of their preimmigration skills and labor market information, as well as the more limited information employers have regarding their skills. Investment in skills and labor market information specific to the destination often entails job turnover and periods of job search. These activities are most intense during the initial period in the destination, and diminish with a longer duration of residence. As a result, the 
employment and unemployment experience of immigrants would be expected to approach that of the native born, other variables being the same.

Among the foreign born, weeks worked are greater and unemployment rates are lower for those with more schooling, and weeks worked increase but unemployment rates are invariant with total labor market experience. The effects of schooling and total experience are weaker among the foreign born than among the native born. Those who are married have greater employment and lower unemployment. Employment in the agricultural sector has a different effect on the foreign born and native born, largely due to differences by nativity in the extent of self-employment (and family employment) versus hired farm labor. Agricultural employment is associated with lower employment and greater unemployment among the foreign born than among the foreign born in other sectors. The foreign born have significantly lower rates of employment (weeks worked) and higher unemployment rates during their first few years in the United States.

Overall, the foreign born worked 1.6 fewer weeks than the native born, but other variables the same they worked only 1.0 fewer weeks. The pattern of fewer weeks of employment varies by duration of residence--5.9 fewer weeks for those in the U.S. 3 or fewer years, with the difference diminishing with duration of residence. Among 
the foreign born, those who are naturalized citizens and those who are fluent in English work more weeks, with each effect approximately 1 week.

Employment also varies by country of origin. Although the differences are small for most countries of origin (generally less than two fewer weeks than the benchmark, the British Isles), the differences are large for immigrants from the USSR (2.8 fewer weeks), Korea (2.1 fewer weeks) and Mexico (2.1 fewer weeks). Among immigrants from the USSR the weeks worked differential is a temporary phenomenon--it is very large for the most recent cohort (1987-90) and diminishes sharply with duration of residence. Comparisons with data from earlier periods indicates that the effects of duration of residence do not reflect changes in cohort quality, but rather a longitudinal effect. That is, it is a consequence of the process of adjustment with duration of residence.

Overall, the foreign born have an unemployment rate about 1.4 percentage points higher than the native born, but other variables the same, they have an unemployment rate that is slightly lower than the native born. The unemployment rate is much higher for the recent foreign born, (1987-90 cohort), but declines sharply to a level that does not vary with duration of residence. Naturalized citizens and those fluent in English have lower unemployment rates. The very high unemployment rates of 
immigrants from the USSR is a short-term refugee effect, and does not differ by duration among other cohorts.

The analysis of unemployment compensation benefits is based on an algorithm developed for this project. The foreign born reported receiving fewer benefits in 1989, due to a significantly lower probability of receiving any benefits. Among those who received unemployment compensation benefits the foreign born received a larger total benefit and a larger weekly benefit.

In conclusion, the analysis finds that immigrants experience fewer weeks worked and higher unemployment rates during the first few years in the U.S., but after that their employment and unemployment experiences are very similar to those of the native born. Among the foreign born those who are citizens and fluent in English work more weeks and have lower unemployment rates. The foreign born in the agricultural sector work fewer weeks and have higher unemployment rates than the foreign born in the rest of the economy and the native born in agriculture. Refugees from the USSR experience very low employment and very high unemployment rates during their first three years, but there are no significant differences thereafter. The foreign born have a lower probability of receiving unemployment compensation benefits and receive less income from this source, other variables the same, although 
foreign-born benefit recipients do receive more in a year than their native-born counterparts.

The unemployment problems associated with immigrants appear therefore to be largely short-term, transitional adjustments not unlike those experienced by nativeborn new entrants and re-entrants to the labor market. 


\section{ACKNOWLEDGEMENT}

This project has been funded by the Advisory Council on Unemployment Compensation, but the views expressed are solely those of the authors. We appreciate the comments received on a preliminary draft of this paper at the Advisory Council's Research Conference on the Reform of the Unemployment Compensation System, Vermont, August 1995. This paper was presented at the ASSA Annual Meetings, San Francisco, January 1996; Cordelia Reimer's discussant comments are appreciated. 


\section{NOTES}

1 For an analysis of the socioeconomic and demographic characteristics of the foreign-born population, based on the 1990 Census of Population, see Chiswick and Sullivan (1995).

2 The discussion in this section draws on Chiswick (1982) and Chiswick, Cohen and Zach (1997).

3 The frequency distribtion (percent) of foreign-born and native-born agricultural workers (industry and occupation) by class of worker (1990) is:

Class of Worker

Born

Private sector

Government sector

Self-employment (including unpaid family wokers)

Total

Source: 1990 Census of Population, Public Use Microdata Sample, 1 percent sample. 
4 Soviet immigrants have a much steeper slope of employment with respect to duration of residence. Those who arrived between 1987 and 1990 worked 13.5 fewer weeks $(t=-15.5)$ than the benchmark, Soviet immigrants who arrived between 1975 and 1979; those who arrived in 1985-86 worked a marginally significant $(t=1.5) 2.4$ more weeks than the benchmark cohort, with no significant differences from the benchmark for any earlier cohort.

5 Soviet immigrants who immigrated in the most recent three-year period, 198790, had an unemployment rate 15.9 percentage points $(t=9.1)$ higher than Soviet immigrants who arrived in the benchmark (1975-79) period. The unemployment rates for earlier cohorts were not significantly different from the benchmark, except for a 6.7 point $(t=2.5)$ higher rate for the $1982-84$ cohort.

6 An alternative procedure would be to include these groups in the sample, but add dichotomous variables for these characteristics to the estimating equation. Tests with this procedure indicate that there are no substantive differences in the findings for the human capital, demographic and immigrant variables. 


\section{References}

Becker, Gary S., (1964), Human Capital, New York: NBER.

Chiswick, Barry R. (1978), "The Effect of Americanization on the Earnings of Foreign-Born Men," Journal of Political Economy, October, pp 897-922.

Chiswick, Barry R., (1979), "The Economic Progress of Immigrants: Some Apparently Universal Patterns" in William Fellner, ed. Contemporary Economic Problems, 1979, Washington: American Enterprise Institute, 1979, pp 357-399.

Chiswick, Barry R., Yinon Cohen and Tzippi Zach (1997), "The Labor Market Status of Immigrants: Effects of Duration of Residence and the Unemployment at Arrival",, Industrial and Labor Relations Review.

Chiswick, Barry R. and Paul W. Miller (1995), "The Endogeneity Between Language and Earnings: International Analyses," Journal of Labor Economics, April, pp. 245287. 
Chiswick, Barry R. and Paul W. Miller (1994), "Language and Labor Supply: The Role of Gender Among Immigrants in Australia," Research on Income Inequality, Vol 5, pp 153-189.

Fields, Harold (1935), "The Unemployed Foreign-Born," Quarterly Journal of Economics, 49, May, pp 433-41.

Leighton, Linda and Jacob Mincer (1982), "Labor Turnover and Youth Unemployment," In Richard B. Freeman and David A. Wise, eds., The Youth Unemployment Problem: Its Nature, Causes and Consequences, Chicago, pp 235-67.

Rubin, Ernest (1947), Unemployment of Aliens in the United States, 1940. Ph.D. dissertation, Columbia University.

U.S. Bureau of the Census (1992), 1990 Census of Population and Housing, Public

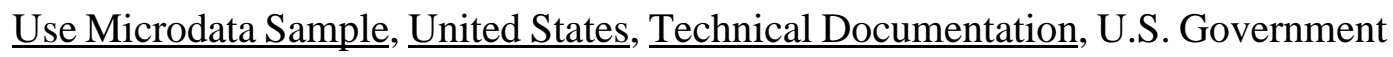
Printing Office, October. 


\section{Figure 1}

\section{List of Dependent and Explanatory Variables}

\begin{tabular}{|c|c|c|}
\hline$\overline{\text { Variable }}$ & $\begin{array}{l}\text { Hypot } \\
\text { Effect }\end{array}$ & $\begin{array}{l}\text { Partial } \\
\text { ployment }\end{array}$ \\
\hline \multicolumn{3}{|l|}{ Dependent Variables } \\
\hline Employment & $\begin{array}{l}\text { Weeks worked in } 1989 \text { among those who } \\
\text { worked and had non-zero earnings in } \\
1989\end{array}$ & \\
\hline Unemployed & $\begin{array}{l}\text { Unemployed among those in the labor force } \\
\text { in the reference week in March } 1990\end{array}$ & \\
\hline $\begin{array}{l}\text { Unemployment } \\
\text { Compensation }\end{array}$ & $\begin{array}{l}\text { Unemployment compensation benefits, proxy } \\
\text { measure }^{(\mathrm{b})}\end{array}$ & \\
\hline \multicolumn{3}{|l|}{ Explanatory Variables } \\
\hline Education & Years of Schooling & + \\
\hline Experience & $\begin{array}{l}\text { Years of labor market experience } \\
\quad(\text { Age-Education-5), and its square }\end{array}$ & + \\
\hline Not married & Not "married, spouse present" = 1 & - \\
\hline Rural & Rural area $=1$ & $?$ \\
\hline South & Southern state and DC $=1$ & $?$ \\
\hline Foreign Born & Foreign born $=1$ & - \\
\hline Naturalized Citizen & Naturalized citizen $=1$, Alien and US born $=0$ & + \\
\hline Speaks English & $\begin{array}{l}\text { Foreign Born and Speaks only English or } \\
\text { Speaks English Very Well = } 1\end{array}$ & + \\
\hline Agriculture & Industry and Occupation is in agriculture $=1$ & (c) \\
\hline Foreign* Agriculture & Foreign born and in Agriculture $=1$ & - \\
\hline
\end{tabular}




\section{Figure 1 Continued}

Years Since Migration

Year of Immigration

Country of Birth
1990 minus year of immigration

Period of immigration dichotomous variables: Immigrated before 1950 (PRE-50) or between 19XX and 19YY.

Dichotomous country of birth variables, British Isles as the benchmark, see Table 1 for details
$+$

(d)

(e)

${ }^{(a)}$ Hypothesized partial effect of the explanatory variable on weeks worked (employment) is positive (+), negative (-), or ambiguous (?). Hypothesized signs are reversed for unemployment status. Analysis limited to males age 25 to 64 .

(b)"All other income" (INCOME 8), with the population limited to adult males who were not veterans, are not disabled, and are not currently in the military or enrolled in school. See Appendix A.

${ }^{(c)}$ Hypothesis is a positive sign for the native born and a negative sign for the foreign born.

${ }^{(d)}$ Hypothesis is that employment increases with duration of residence.

${ }^{(e)}$ Hypothesis is that employment is lower for immigrants from non-English speaking countries, and lower for recent refugees than for economic migrants.

Note: The sample is limited to native-born and foreign-born males age 25 to 64 years in 1990, who worked in at least one week and had non-zero earnings (wage, salary and self-employment income) in 1989. Persons born abroad of American parents and persons born in a territory of the United States are excluded from the analysis. 
TABLE 1

Means and Standard Deviations, Native-Born and Foreign-Born Men

Aged 25-64, 1990

\begin{tabular}{|c|c|c|c|c|c|c|}
\hline \multirow[b]{2}{*}{ Variable } & \multicolumn{2}{|c|}{ Native Born } & \multicolumn{2}{|c|}{ Foreign Born } & \multicolumn{2}{|c|}{ Total } \\
\hline & Mean & $\begin{array}{r}\text { Standard } \\
\text { Deviation } \\
\end{array}$ & Mean & $\begin{array}{l}\text { Standard } \\
\text { Deviation } \\
\end{array}$ & Mean & $\begin{array}{l}\text { Standard } \\
\text { Deviation } \\
\end{array}$ \\
\hline Weeks Worked & 47.36 & 10.50 & 45.76 & 11.59 & 47.19 & 10.64 \\
\hline Unemployment Rate & 4.82 & 2.14 & 6.18 & 1.12 & 4.94 & 2.18 \\
\hline UI Benefits Received & 78.59 & 7430.96 & 61.75 & 3347.86 & 76.64 & 7503.93 \\
\hline UI Benefits, with UI & 2692.39 & 33479.34 & 2894.67 & 18360.16 & 2708.86 & 34658.85 \\
\hline Education & 13.47 & 2.66 & 11.95 & 4.78 & 13.32 & 2.98 \\
\hline Experience & 22.04 & 11.13 & 22.73 & 11.45 & 22.10 & 11.16 \\
\hline Experience Squared & 609.38 & 572.94 & 647.70 & 612.94 & 613.07 & 577.30 \\
\hline Not Married & 0.31 & 0.46 & 0.34 & 0.47 & 0.31 & 0.46 \\
\hline Rural & 0.27 & 0.45 & 0.06 & 0.24 & 0.25 & 0.43 \\
\hline South & 0.34 & 0.47 & 0.24 & 0.43 & 0.33 & 0.47 \\
\hline Agriculture & 0.03 & 0.16 & 0.05 & 0.21 & 0.03 & 0.16 \\
\hline Foreign born & 0.00 & 0.00 & 1.00 & 0.00 & 0.10 & 0.30 \\
\hline \multicolumn{7}{|l|}{ Year of Immigration } \\
\hline Pre - 1950 & & & 0.024 & 0.154 & 0.003 & 0.050 \\
\hline $1950-1959$ & & & 0.086 & 0.281 & 0.009 & 0.093 \\
\hline 1960-1964 & & & 0.078 & 0.268 & 0.008 & 0.087 \\
\hline 1965-1969 & & & 0.104 & 0.306 & 0.010 & 0.101 \\
\hline 1970-1974 & & & 0.137 & 0.344 & 0.013 & 0.115 \\
\hline 1975-1979 & & & 0.174 & 0.379 & 0.017 & 0.130 \\
\hline 1980-1981 & & & 0.117 & 0.321 & 0.012 & 0.107 \\
\hline 1982-1984 & & & 0.098 & 0.297 & 0.009 & 0.097 \\
\hline 1985-1986 & & & 0.081 & 0.273 & 0.008 & 0.089 \\
\hline 1987-1990 & & & 0.101 & 0.301 & 0.010 & 0.102 \\
\hline Naturalized Citizen & & & 0.411 & 0.492 & 0.041 & 0.197 \\
\hline Speaks English & & & 0.520 & 0.500 & 0.052 & 0.222 \\
\hline \multicolumn{7}{|l|}{ Countries of Birth } \\
\hline British Isles & & & 0.036 & 0.185 & 0.004 & 0.060 \\
\hline
\end{tabular}


TABLE 1 Continued

\begin{tabular}{|c|c|c|c|c|c|c|}
\hline \multirow[b]{2}{*}{ Variable } & \multicolumn{2}{|c|}{ Native Born } & \multicolumn{2}{|c|}{ Foreign Born } & \multicolumn{2}{|c|}{ Total } \\
\hline & Mean & $\begin{array}{l}\text { Standard } \\
\text { Deviation }\end{array}$ & Mean & $\begin{array}{l}\text { Standard } \\
\text { Deviation }\end{array}$ & Mean & $\begin{array}{l}\text { Standard } \\
\text { Deviation }\end{array}$ \\
\hline Western Europe & & & 0.050 & 0.217 & 0.005 & 0.070 \\
\hline Eastern Europe & & & 0.025 & 0.157 & 0.003 & 0.051 \\
\hline Southern Europe & & & 0.056 & 0.231 & 0.006 & 0.076 \\
\hline Balkans & & & 0.013 & 0.114 & 0.001 & 0.037 \\
\hline USSR & & & 0.011 & 0.105 & 0.001 & 0.034 \\
\hline Canada/Aust/NZ & & & 0.035 & 0.183 & 0.003 & 0.057 \\
\hline Mexico & & & 0.232 & 0.422 & 0.023 & 0.150 \\
\hline Cuba & & & 0.042 & 0.200 & 0.004 & 0.064 \\
\hline Brit. W. Indies & & & 0.029 & 0.169 & 0.003 & 0.055 \\
\hline Other Lat. America & & & 0.143 & 0.350 & 0.015 & 0.120 \\
\hline North Africa & & & 0.046 & 0.210 & 0.004 & 0.066 \\
\hline Other Africa & & & 0.018 & 0.134 & 0.002 & 0.045 \\
\hline Southwest Asia & & & 0.043 & 0.202 & 0.004 & 0.064 \\
\hline Indochina & & & 0.034 & 0.182 & 0.003 & 0.059 \\
\hline China & & & 0.050 & 0.219 & 0.005 & 0.070 \\
\hline Japan & & & 0.012 & 0.111 & 0.001 & 0.035 \\
\hline Philippines & & & 0.044 & 0.205 & 0.004 & 0.065 \\
\hline Korea & & & 0.026 & 0.159 & 0.003 & 0.051 \\
\hline Other Asia & & & 0.013 & 0.115 & 0.001 & 0.037 \\
\hline Other Countries & & & 0.039 & 0.195 & 0.004 & 0.061 \\
\hline Observations & 496,382 & & 251,739 & & 546,545 & \\
\hline
\end{tabular}

(a) Other countries includes other countries not listed, at sea and, the largest category, country of birth not reported.

Source: 1990 Census of Population, Public Use Microdata Sample, 1 percent sample of the native born and total, 5 percent sample of the foreign born. 
TABLE 2

Regression Analysis of Weeks Worked, for Pooled Native and Foreign-Born Adult Men, 1990

\section{Native Born}

(1)

Variable

Education

Experience

Experience Squared

Not Married

Rural

South

Agriculture

Foreign born

Foreign* Agriculture

Years of Migration

Pre-1950

1950-1959

1960-1964

1965-1969

1970-1974

1975-1979

1980-1981

1982-1984

1985-1986
0.36879

(61.90)

0.21119

(36.29)

$-0.00504$

$(-44.54)$

$-3.49135$

$(-105.77)$

$-0.01379$

$(-0.40)$

$-0.07010$

(-2.26)

$-1.49781$

$(-15.87)$

(a)

(a)

(a)

(a)

(a)

(a)

(a)

(a)

(a)

(a)

(a) - - - -
Pooled Native and Foreign Born

(2)

(3)

(4)

0.32903

(61.73)

0.20505

(36.98)

$-0.00484$

$(-45.08)$

$-3.40078$

(-107.08)

$-0.03359$

(-0.99)

$-0.09550$

(-3.17)

$-1.74288$

(-19.78)

(a)

(-19.84)

$-1.36589$

$(-5.78)$

(a)

(a)

(a)

0.40412

$-0.62988$

(1.44)

$(-2.07)$

0.22523

$-0.73001$

(1.48)

(-3.90)

0.07724

$-0.75439$

(0.48)

(-4.02)

0.23033

(1.65)

$-0.51029$

(-3.13)

$-0.22213$

(-1.81)

$-0.84389$

(-5.95)

$-1.09778$

$(-8.79)$

$(-5.24)$

$-1.43232$

(-10.20)

$-1.55043$

(-10.11)

$-1.56678$

$(-9.63)$ 
TABLE 2 continued

\section{Native Born}

Naturalized Citizen

Speaks English

Constant

Adjusted R2

Standard Error

Observations
(1)

(a)

(a)

(a)

41.95137

(380.96)

0.0436

10.27686 496,351 --------- Pooled Native and Foreign Born

(2)

(3)

(4)

(a)

$-5.92740$

$-6.16612$

(-42.71)

(a)

$(-42.80)$

0.70984

(6.78)

0.47447

(4.95)

42.48890

(413.94)

(415.87)

42.38369

(416.51)

0.0479

10.4377

546,513

Notes: (a) Variable not entered t-ratios in parentheses

Source: 1990 Census of Population, Public Use Microdata Sample, 1 percent sample 
TABLE 3

Regression Analysis of Weeks Worked, for Foreign-Born Adult Men, 1990

Variable

Education
Experience
Experience Squared
Not Married
Rural
South
Agriculture
Year of Immigration

Pre-1950

1950-1959

1960-1964

1965-1969

1970-1974

1980-1981

1982-1984

1985-1986

$1987-1990$

Naturalized Citizen

Speaks English

Countries of Birth

Western Europe
(1)

(2)

(3)

(4)

0.16729

(24.67)

0.15662

(18.75)

$-0.00309$

$(-20.22)$

$-2.40809$

$(-48.01)$

0.08031

(0.82)

$-0.30102$

$(-5.50)$

$-3.66187$

$(-31.82)$

$(-37.01)$

$-4.08308$

$(-35.93)$

$-0.13306$

$(-0.84)$

0.51351

(5.24)

0.53186

(5.41)

(a)

0.39561

(4.46)

(a)

0.03375

$(0.42)$

(a)

$-0.27534$

(-3.25)

(a)

$-0.78247$

(-8.71)

(a)

$-1.47232$

(-15.37)

$-5.44074$

(-60.71)

(a)

(a)

$-0.86041$

$(-5.32)$

$-1.21443$

$(-7.32)$

$-0.06881$

$(-0.68)$

0.12371

(1.24)

0.10726

(1.20)

$-0.10922$

(-1.34)

$-0.10199$

(-1.20)

$-0.53766$

(-5.94)

$-1.09868$

$(-11.29)$

$-5.00649$

(-54.60)

0.85707

(16.24)

0.91098

(17.67)

$-0.49781$

$(-4.70)$

$-0.19653$

(-1.91)

$-0.11872$

(-1.30)

$-0.15897$

(-1.94)

$-0.21626$

$(-2.53)$

$-0.65133$

$(-7.16)$

$-1.23371$

$(-12.61)$

$-5.24298$

(-56.54)

0.82704

(15.25)

0.74868

(13.49)

(a) $\quad-0.45000$

$(-2.88)$ 
TABLE 3 Continued

Variable

Eastern Europe

Southern Europe

Balkans

USSR

Canada/Aust/NZ

Mexico

Cuba

Brit. W. Indies

Other Lat. America

North Africa

Other Africa

Southwest Asia

Indochina

China

Japan

Philippines

Korea

Other Asia

Other Countries

Constant (a)

(a)

(a)

(a)

(a)

(a)

(a)

(a)

(a)

(a)

(a)

(a)

(a)

(a)

(a)

(a)

(a)

(a)

(a)

40.91252

(299.14)

\section{(1)}

\begin{abstract}
(2)
\end{abstract}
(a)

(a)

(3)

(4)

(a)

(a)

(a)

(a)

(a)

(a)

(a)

(a)

(a)

(a)

(a)

(a)

(a)

(a)

(a)

(a)

(a)

(a)

(a)

(a)

42.95727 (291.72)
$-0.33285$

$(-1.80)$

$-0.46766$

$(-3.02)$

$-0.87699$

$(-3.83)$

$-2.78040$

$(-11.38)$

$-0.49322$

$(-2.88)$

$-2.07228$

$(-15.07)$

$-0.72390$

(-4.31)

$-1.85110$

(-10.41)

$-1.43230$

(-10.46)

$-1.62805$

(-10.19)

$-2.03329$

(-10.26)

$-1.30062$ (-8.01)

$-1.08968$

(-6.19)

$-1.49728$ $(-9.42)$

0.90066 (3.82)

$-1.06157$ (-6.57)

$-2.11499$

(-11.30)

$-1.01892$ (-4.47)

$-2.31583$

(-13.91) 44.73148 (215.06) 
TABLE 3 Continued

Variable

Adjusted R ${ }^{2}$

Standard Error

Observations
(1)
(2)

(3)

(4)

0.0420
11.84162
251,720

0.0617

11.71920

251,720
0.0670

11.68611

251,720

Notes: (a) Variable not entered $\mathrm{t}$-ratios in parentheses

Source: 1990 Census of Population, Public Use Microdata Sample, 1 percent sample. 
TABLE 4

Regression Analysis of Unemployment, for Native-Born and Foreign-Born Adult Men, 1990

\begin{tabular}{|c|c|c|c|c|c|}
\hline \multirow[b]{2}{*}{ Variable } & \multirow{2}{*}{$\begin{array}{r}\begin{array}{r}\text { Native } \\
\text { Born }\end{array} \\
(1) \\
\end{array}$} & \multicolumn{2}{|c|}{$\begin{array}{c}\text { Pooled Native and } \\
\text { Foreign Born } \\
\end{array}$} & \multicolumn{2}{|c|}{ Foreign Born } \\
\hline & & (2) & (3) & (4) & (5) \\
\hline Education & $\begin{array}{r}-0.00908 \\
(-72.98)\end{array}$ & $\begin{array}{r}-0.00780 \\
(-71.86)\end{array}$ & $\begin{array}{r}-0.00784 \\
(-70.68)\end{array}$ & $\begin{array}{r}-0.00422 \\
(-37.05)\end{array}$ & $\begin{array}{r}-0.00308 \\
(-21.51)\end{array}$ \\
\hline Experience & $\begin{array}{r}0.00190 \\
(15.45)\end{array}$ & $\begin{array}{r}0.00152 \\
(12.98)\end{array}$ & $\begin{array}{r}0.00155 \\
(13.20)\end{array}$ & $\begin{array}{r}-0.00008 \\
(-0.48)\end{array}$ & $\begin{array}{r}0.00019 \\
(1.07)\end{array}$ \\
\hline Experience Squared & $\begin{array}{r}-0.00004 \\
(-17.97)\end{array}$ & $\begin{array}{r}-0.00003 \\
(-15.19)\end{array}$ & $\begin{array}{r}-0.00004 \\
(-15.39)\end{array}$ & $\begin{array}{r}0.00000 \\
(1.24)\end{array}$ & $\begin{array}{r}0.00000 \\
(0.90)\end{array}$ \\
\hline Not Married & $\begin{array}{r}0.05440 \\
(79.18)\end{array}$ & $\begin{array}{r}0.05175 \\
(78.33)\end{array}$ & $\begin{array}{r}0.05160 \\
(78.02)\end{array}$ & $\begin{array}{r}0.03257 \\
(31.12)\end{array}$ & $\begin{array}{r}0.02805 \\
(26.34)\end{array}$ \\
\hline Rural & $\begin{array}{r}-0.00318 \\
(-4.49)\end{array}$ & $\begin{array}{r}-0.00240 \\
(-3.40)\end{array}$ & $\begin{array}{r}-0.00253 \\
(-3.58)\end{array}$ & $\begin{array}{r}-0.00887 \\
(-4.30)\end{array}$ & $\begin{array}{r}-0.00333 \\
(-1.59)\end{array}$ \\
\hline South & $\begin{array}{r}-0.00749 \\
(-11.61)\end{array}$ & $\begin{array}{r}-0.00695 \\
(-11.06)\end{array}$ & $\begin{array}{r}-0.00692 \\
(-11.01)\end{array}$ & $\begin{array}{r}-0.00690 \\
(-6.16)\end{array}$ & $\begin{array}{r}-0.00854 \\
(-7.34)\end{array}$ \\
\hline Agriculture & $\begin{array}{r}-0.00722 \\
(-3.65)\end{array}$ & $\begin{array}{r}-0.00607 \\
(-3.02)\end{array}$ & $\begin{array}{r}-0.00425 \\
(-2.31)\end{array}$ & $\begin{array}{r}0.03217 \\
(13.37)\end{array}$ & $\begin{array}{r}0.02989 \\
(12.25)\end{array}$ \\
\hline Foreign born & (a) & $\begin{array}{r}-0.00346 \\
(-3.42)\end{array}$ & (a) & (a) & (a) \\
\hline Foreign* Agriculture & & $\begin{array}{r}0.01140 \\
(2.33)\end{array}$ & (a) & (a) & (a) \\
\hline \multicolumn{6}{|l|}{ Year of Immigration } \\
\hline Pre-1950 & (a) & (a) & $\begin{array}{r}0.00196 \\
(0.31)\end{array}$ & (a) & $\begin{array}{r}0.00210 \\
(0.58)\end{array}$ \\
\hline $1950-1959$ & (a) & (a) & $\begin{array}{r}0.00328 \\
(0.84)\end{array}$ & (a) & $\begin{array}{r}0.00491 \\
(2.17)\end{array}$ \\
\hline $1960-1964$ & (a) & (a) & $\begin{array}{r}-0.00679 \\
(-1.75)\end{array}$ & (a) & $\begin{array}{r}0.00654 \\
(2.98)\end{array}$ \\
\hline $1965-1969$ & (a) & (a) & $\begin{array}{r}0.00167 \\
(0.50)\end{array}$ & (a) & $\begin{array}{r}0.00780 \\
(4.01)\end{array}$ \\
\hline 1970-1974 & (a) & (a) & $\begin{array}{r}-0.00440 \\
(-1.51)\end{array}$ & (a) & $\begin{array}{r}0.00617 \\
(3.53)\end{array}$ \\
\hline $1975-1979$ & (a) & (a) & $\begin{array}{r}-0.00153 \\
(-0.60)\end{array}$ & (a) & (a) \\
\hline 1980-1981 & (a) & (a) & $\begin{array}{r}-0.01033 \\
(-3.58)\end{array}$ & (a) & $\begin{array}{r}0.00278 \\
(1.54)\end{array}$ \\
\hline $1982-1984$ & (a) & (a) & $\begin{array}{r}-0.00591 \\
(-1.87)\end{array}$ & (a) & $\begin{array}{r}-0.00343 \\
(-1.77)\end{array}$ \\
\hline $1985-1986$ & (a) & (a) & $\begin{array}{r}-0.00418 \\
(-1.25)\end{array}$ & (a) & $\begin{array}{r}0.00088 \\
(0.42)\end{array}$ \\
\hline
\end{tabular}


TABLE 4 Continued

\begin{tabular}{|c|c|c|c|c|c|}
\hline \multirow[b]{2}{*}{ Variable } & \multirow{2}{*}{$\begin{array}{c}\begin{array}{c}\text { Native } \\
\text { Born }\end{array} \\
(1)\end{array}$} & \multicolumn{2}{|c|}{$\begin{array}{c}\text { Pooled Native and } \\
\text { Foreign Born }\end{array}$} & \multicolumn{2}{|c|}{ Foreign Born } \\
\hline & & $(2)$ & (3) & (4) & (5) \\
\hline $1987-1990$ & (a) & (a) & $\begin{array}{r}0.01264 \\
(4.40)\end{array}$ & (a) & $\begin{array}{r}0.03046 \\
(15.78)\end{array}$ \\
\hline Naturalized Citizen & (a) & (a) & $\begin{array}{r}-0.00806 \\
(-3.74)\end{array}$ & (a) & $\begin{array}{r}-0.01188 \\
(-10.30)\end{array}$ \\
\hline Speaks English & (a) & (a) & $\begin{array}{r}0.00336 \\
(1.70)\end{array}$ & (a) & $\begin{array}{r}-0.00919 \\
(-7.80)\end{array}$ \\
\hline \multicolumn{6}{|l|}{ Countries of Birth } \\
\hline Western Europe & (a) & (a) & (a) & (a) & $\begin{array}{r}0.00203 \\
(0.60)\end{array}$ \\
\hline Eastern Europe & (a) & (a) & (a) & (a) & $\begin{array}{r}0.00908 \\
(2.30)\end{array}$ \\
\hline Southern Europe & (a) & (a) & (a) & (a) & $\begin{array}{r}0.00689 \\
(2.08)\end{array}$ \\
\hline Balkans & (a) & (a) & (a) & (a) & $\begin{array}{r}0.01196 \\
(2.45)\end{array}$ \\
\hline USSR & (a) & (a) & (a) & (a) & $\begin{array}{r}0.08109 \\
(15.85)\end{array}$ \\
\hline Canada/Aust/NZ & (a) & (a) & (a) & (a) & $\begin{array}{r}0.00628 \\
(1.71)\end{array}$ \\
\hline Mexico & (a) & (a) & (a) & (a) & $\begin{array}{r}0.01675 \\
(5.70)\end{array}$ \\
\hline Cuba & (a) & (a) & (a) & (a) & $\begin{array}{r}0.01450 \\
(4.04)\end{array}$ \\
\hline Brit. W. Indies & (a) & (a) & (a) & (a) & $\begin{array}{r}0.04246 \\
(11.21)\end{array}$ \\
\hline Other Lat. America & (a) & (a) & (a) & (a) & $\begin{array}{r}0.02245 \\
(7.67)\end{array}$ \\
\hline North Africa & (a) & (a) & (a) & (a) & $\begin{array}{r}0.02302 \\
\quad(6.75)\end{array}$ \\
\hline Other Africa & (a) & (a) & (a) & (a) & $\begin{array}{r}0.02303 \\
\quad(5.45)\end{array}$ \\
\hline Southwest Asia & (a) & (a) & (a) & (a) & $\begin{array}{r}0.01170 \\
(3.37)\end{array}$ \\
\hline Indochina & (a) & (a) & (a) & (a) & $\begin{array}{r}0.02453 \\
(6.56)\end{array}$ \\
\hline China & (a) & (a) & (a) & (a) & $\begin{array}{r}0.00129 \\
(0.38)\end{array}$ \\
\hline Japan & (a) & (a) & (a) & (a) & $\begin{array}{r}-0.03391 \\
(-6.68)\end{array}$ \\
\hline Philippines & (a) & (a) & (a) & (a) & $\begin{array}{r}0.00338 \\
(0.98)\end{array}$ \\
\hline
\end{tabular}


TABLE 4 Continued

\begin{tabular}{|c|c|c|c|c|c|}
\hline \multirow[b]{2}{*}{ Variable } & \multirow{2}{*}{$\begin{array}{c}\begin{array}{c}\text { Native } \\
\text { Born }\end{array} \\
(1)\end{array}$} & \multicolumn{2}{|c|}{$\begin{array}{l}\text { Pooled Native and } \\
\text { Foreign Born }\end{array}$} & \multicolumn{2}{|c|}{ Foreign Born } \\
\hline & & (2) & (3) & (4) & (5) \\
\hline Korea & (a) & (a) & (a) & (a) & $\begin{array}{r}-0.00601 \\
(-1.50)\end{array}$ \\
\hline Other Asia & (a) & (a) & (a) & (a) & $\begin{array}{r}0.00757 \\
(1.55)\end{array}$ \\
\hline Other Countries & (a) & (a) & (a) & (a) & $\begin{array}{r}0.03021 \\
(8.53)\end{array}$ \\
\hline Constant & $\begin{array}{r}0.14206 \\
(61.67)\end{array}$ & $\begin{array}{r}0.12829 \\
(60.53)\end{array}$ & $\begin{array}{r}0.12858 \\
(59.98)\end{array}$ & $\begin{array}{r}0.10080 \\
(35.01)\end{array}$ & $\begin{array}{r}0.07215 \\
(16.27)\end{array}$ \\
\hline Adjusted $\mathrm{R}^{2}$ & 0.0264 & 0.0240 & 0.0241 & 0.0145 & 0.0198 \\
\hline Standard Error & 0.21132 & 0.21511 & 0.21510 & 0.24938 & 0.24870 \\
\hline Observations & 485,338 & 535,823 & 535,823 & 253,377 & 253,377 \\
\hline
\end{tabular}

Notes: (a) Variable not entered t-ratios in parentheses

Source: 1990 Census of Population, Public Use Microdata Sample, 1 percent sample for the native born and pooled analysis, and 5 percent sample for the foreign born analysis. 
TABLE 5

Logistic Regression Analysis of Unemployment, for Native and Foreign-Born Adult Men, 1990 Native Pooled Native and

Born Foreign Born $\quad$ Foreign Born

\begin{tabular}{|c|c|c|c|c|c|}
\hline Variable & (1) & (2) & (3) & (4) & (5) \\
\hline Education & $\begin{array}{r}-0.18100 \\
(-70.16)\end{array}$ & $\begin{array}{r}-0.14490 \\
(-67.71)\end{array}$ & $\begin{array}{r}-0.14630 \\
(-66.50)\end{array}$ & $\begin{array}{r}-0.06730 \\
(-16.74)\end{array}$ & $\begin{array}{r}-0.04560 \\
(-20.18)\end{array}$ \\
\hline Experience & $\begin{array}{r}0.03450 \\
(12.73)\end{array}$ & $\begin{array}{r}0.02340 \\
(9.44)\end{array}$ & $\begin{array}{r}0.02380 \\
(9.60)\end{array}$ & $\begin{array}{r}-0.00310 \\
(-0.48)\end{array}$ & $\begin{array}{r}0.00073 \\
(0.25)\end{array}$ \\
\hline Experience Squared & $\begin{array}{r}-0.00084 \\
(-15.85)\end{array}$ & $\begin{array}{r}-0.00058 \\
(-12.34)\end{array}$ & $\begin{array}{r}-0.00059 \\
(-12.55)\end{array}$ & $\begin{array}{r}0.00008 \\
(0.71)\end{array}$ & $\begin{array}{r}0.00008 \\
(1.57)\end{array}$ \\
\hline Not Married & $\begin{array}{r}1.05290 \\
(73.63)\end{array}$ & $\begin{array}{r}0.98770 \\
(74.26)\end{array}$ & $\begin{array}{r}0.98630 \\
(73.60)\end{array}$ & $\begin{array}{r}0.53310 \\
(14.25)\end{array}$ & $\begin{array}{r}0.45520 \\
(26.47)\end{array}$ \\
\hline Rural & $\begin{array}{r}-0.02590 \\
(-1.62)\end{array}$ & $\begin{array}{r}-0.01210 \\
(-0.78)\end{array}$ & $\begin{array}{r}-0.01410 \\
(-0.90)\end{array}$ & $\begin{array}{r}-0.15480 \\
(-1.94)\end{array}$ & $\begin{array}{r}-0.05770 \\
(-1.58)\end{array}$ \\
\hline South & $\begin{array}{r}-0.18300 \\
(-12.36)\end{array}$ & $\begin{array}{r}-0.15930 \\
(-11.38)\end{array}$ & $\begin{array}{r}-0.15870 \\
(-11.34)\end{array}$ & $\begin{array}{r}-0.12930 \\
(-2.98)\end{array}$ & $\begin{array}{r}-0.15400 \\
(-7.62)\end{array}$ \\
\hline Agriculture & $\begin{array}{r}-0.16680 \\
(-3.83)\end{array}$ & $\begin{array}{r}-0.12640 \\
(-2.93)\end{array}$ & $\begin{array}{r}-0.12060 \\
(-3.26)\end{array}$ & $\begin{array}{r}0.35090 \\
(5.01)\end{array}$ & $\begin{array}{r}0.31250 \\
(9.70)\end{array}$ \\
\hline Foreign born & (a) & $\begin{array}{r}-0.19980 \\
(-9.08)\end{array}$ & (a) & (a) & (a) \\
\hline Foreign* Agriculture & (a) & $\begin{array}{r}0.01350 \\
(0.17)\end{array}$ & (a) & (a) & (a) \\
\hline \multicolumn{6}{|l|}{ Year of Immigration } \\
\hline Pre-1950 & (a) & (a) & $\begin{array}{r}-0.06590 \\
(-0.44)\end{array}$ & (a) & $\begin{array}{r}0.01600 \\
(0.23)\end{array}$ \\
\hline 1950-1959 & (a) & (a) & $\begin{array}{r}0.01760 \\
(0.21)\end{array}$ & (a) & $\begin{array}{r}0.07400 \\
(1.77)\end{array}$ \\
\hline $1960-1964$ & (a) & (a) & $\begin{array}{r}-0.25860 \\
(-2.97)\end{array}$ & (a) & $\begin{array}{r}0.11110 \\
(2.83)\end{array}$ \\
\hline 1965-1969 & (a) & (a) & $\begin{array}{r}-0.05470 \\
(-0.81)\end{array}$ & (a) & $\begin{array}{r}0.13960 \\
(4.13)\end{array}$ \\
\hline 1970-1974 & (a) & (a) & $\begin{array}{r}-0.20170 \\
(-3.48)\end{array}$ & (a) & $\begin{array}{r}0.10700 \\
(3.59)\end{array}$ \\
\hline 1975-1979 & (a) & (a) & $\begin{array}{r}-0.18860 \\
(-3.79)\end{array}$ & (a) & (a) \\
\hline $1980-1981$ & (a) & (a) & $\begin{array}{r}-0.35890 \\
(-6.25)\end{array}$ & (a) & $\begin{array}{r}0.05030 \\
(1.67)\end{array}$ \\
\hline $1982-1984$ & (a) & (a) & $\begin{array}{r}-0.31450 \\
(-4.97)\end{array}$ & (a) & $\begin{array}{r}-0.06910 \\
(-2.04)\end{array}$ \\
\hline $1985-1986$ & (a) & (a) & $\begin{array}{r}-0.30510 \\
(-4.79)\end{array}$ & (a) & $\begin{array}{r}0.00882 \\
(0.26)\end{array}$ \\
\hline
\end{tabular}


TABLE 5 Continued

\begin{tabular}{|c|c|c|c|c|c|}
\hline \multirow[b]{2}{*}{ Variable } & \multirow{2}{*}{$\begin{array}{c}\text { Native } \\
\text { Born } \\
(1) \\
\end{array}$} & \multicolumn{2}{|c|}{$\begin{array}{c}\text { Pooled Native and } \\
\text { Foreign Born }\end{array}$} & \multicolumn{2}{|c|}{ Foreign Born } \\
\hline & & (2) & (3) & (4) & (5) \\
\hline $1987-1990$ & (a) & (a) & $\begin{array}{r}-0.06980 \\
(-1.36)\end{array}$ & (a) & $\begin{array}{r}0.40840 \\
(13.89)\end{array}$ \\
\hline Naturalized Citizen & (a) & (a) & $\begin{array}{r}-0.16720 \\
(-3.70)\end{array}$ & (a) & $\begin{array}{r}-0.23780 \\
(-11.77)\end{array}$ \\
\hline Speaks English & (a) & (a) & $\begin{array}{r}0.10650 \\
(2.63)\end{array}$ & (a) & $\begin{array}{r}-0.18610 \\
(-9.31)\end{array}$ \\
\hline Countries of Birth & & & & & \\
\hline Western Europe & (a) & (a) & (a) & (a) & $\begin{array}{r}0.03410 \\
(0.45)\end{array}$ \\
\hline Eastern Europe & (a) & (a) & (a) & (a) & $\begin{array}{r}0.26640 \\
(3.31)\end{array}$ \\
\hline Southern Europe & (a) & (a) & (a) & (a) & $\begin{array}{r}0.26380 \\
(3.81)\end{array}$ \\
\hline Balkans & (a) & (a) & (a) & (a) & $\begin{array}{r}0.34320 \\
(3.60)\end{array}$ \\
\hline USSR & (a) & (a) & (a) & (a) & $\begin{array}{r}1.28200 \\
(15.93)\end{array}$ \\
\hline Canada/Aust/NZ & (a) & (a) & (a) & (a) & $\begin{array}{r}0.18820 \\
(2.38)\end{array}$ \\
\hline Mexico & (a) & (a) & (a) & (a) & $\begin{array}{r}0.41260 \\
(6.63)\end{array}$ \\
\hline Cuba & (a) & (a) & (a) & (a) & $\begin{array}{r}0.38100 \\
(5.24)\end{array}$ \\
\hline Brit. W. Indies & (a) & (a) & (a) & (a) & $\begin{array}{r}0.84520 \\
(11.97)\end{array}$ \\
\hline Other Lat. America & (a) & (a) & (a) & (a) & $\begin{array}{r}0.49820 \\
(8.02)\end{array}$ \\
\hline North Africa & (a) & (a) & (a) & (a) & $\begin{array}{r}0.51690 \\
(7.36)\end{array}$ \\
\hline Other Africa & (a) & (a) & (a) & (a) & $\begin{array}{r}0.51630 \\
(6.27)\end{array}$ \\
\hline Southwest Asia & (a) & (a) & (a) & (a) & $\begin{array}{r}0.22400 \\
(2.98)\end{array}$ \\
\hline Indochina & (a) & (a) & (a) & (a) & $\begin{array}{r}0.54250 \\
(7.47)\end{array}$ \\
\hline China & (a) & (a) & (a) & (a) & $\begin{array}{r}0.03760 \\
(0.51)\end{array}$ \\
\hline Japan & (a) & (a) & (a) & (a) & $\begin{array}{r}-1.41060 \\
(-7.70)\end{array}$ \\
\hline Philippines & (a) & (a) & (a) & (a) & $\begin{array}{r}0.08330 \\
(1.10)\end{array}$ \\
\hline
\end{tabular}


TABLE 5 Continued

\begin{tabular}{|c|c|c|c|c|c|}
\hline \multirow[b]{2}{*}{ Variable } & \multirow{2}{*}{$\begin{array}{c}\begin{array}{c}\text { Native } \\
\text { Born }\end{array} \\
(1)\end{array}$} & \multicolumn{2}{|c|}{$\begin{array}{l}\text { Pooled Native and } \\
\text { Foreign Born }\end{array}$} & \multicolumn{2}{|c|}{ Foreign Born } \\
\hline & & (2) & (3) & (4) & (5) \\
\hline Korea & (a) & (a) & (a) & (a) & $\begin{array}{r}-0.19510 \\
(-2.13)\end{array}$ \\
\hline Other Asia & (a) & (a) & (a) & (a) & $\begin{array}{r}0.19440 \\
(1.93)\end{array}$ \\
\hline Other Countries & (a) & (a) & (a) & (a) & $\begin{array}{r}0.60300 \\
(8.89)\end{array}$ \\
\hline Constant & $\begin{array}{r}-1.26420 \\
(-25.64)\end{array}$ & $\begin{array}{r}-1.60940 \\
(-36.33)\end{array}$ & $\begin{array}{r}-1.59200 \\
(-35.54)\end{array}$ & $\begin{array}{r}-2.15650 \\
(-19.82)\end{array}$ & $\begin{array}{r}-2.75170 \\
(-32.68)\end{array}$ \\
\hline AIC & 131,005 & 187,513 & 142,437 & 25,583 & 127,907 \\
\hline Observations & 485,339 & 535,824 & 535,824 & 253,378 & 253,378 \\
\hline
\end{tabular}

Notes: (a) Variable not entered

Asymptotic t-ratios in parentheses

Source: 1990 Census of Population, Public Use Microdata Sample, 1 percent sample for the native born and pooled analysis, and 5 percent sample for the foreign born analysis. 
TABLE 6

Tobit Regression Analysis of Unemployment Insurance Benefit Payments Pooled Native and Foreign-Born Adult Men, 1990

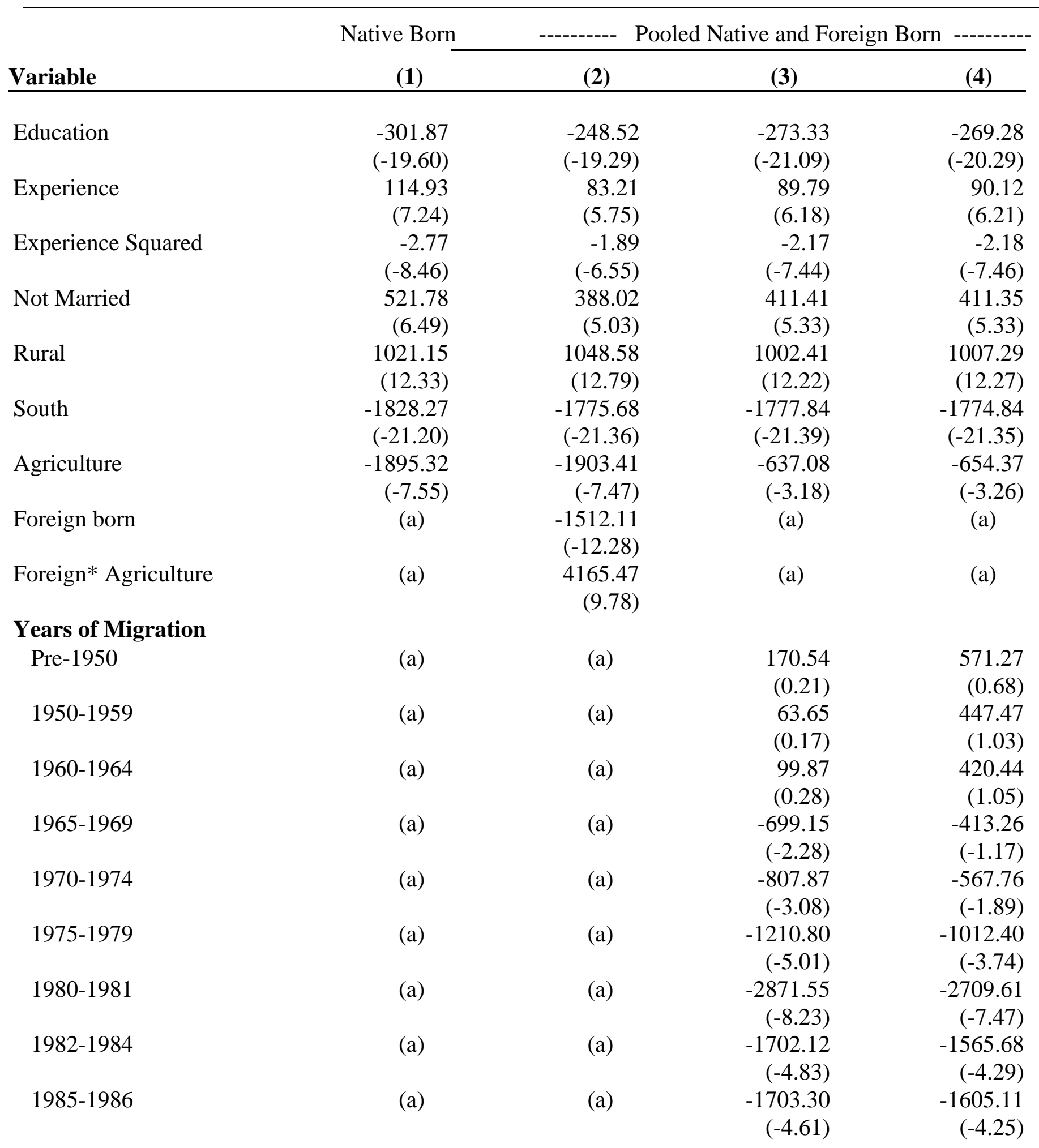


TABLE 6 continued

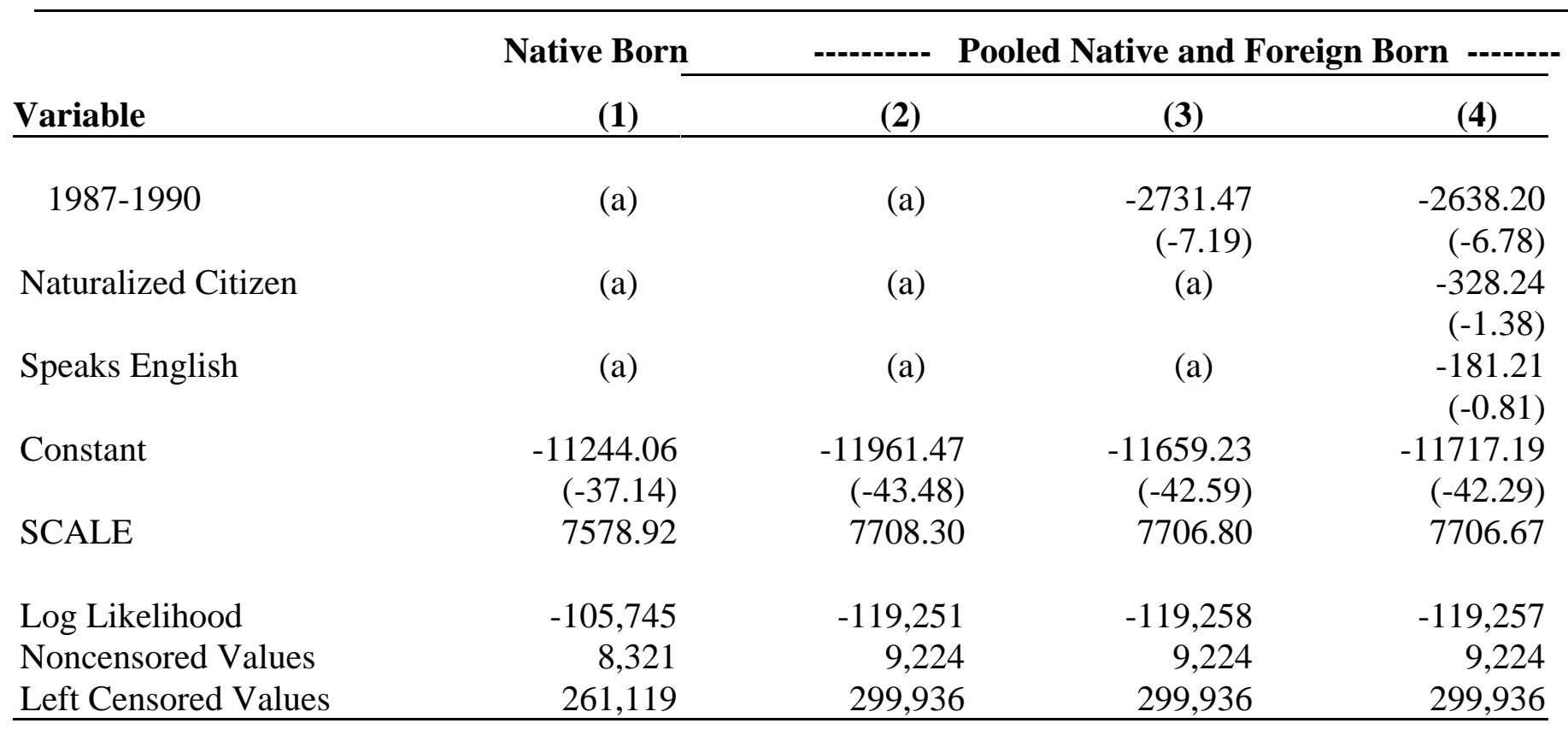

Notes: (a) Variable not entered t-ratios in parentheses

Source: 1990 Census of Population, Public Use Microdata Sample, 1 percent sample 
TABLE 7

Signs of Partial Effects of Variables on Four Measures of Unemployment Insurance Benefits For Adult Men , Pooled Native and Foreign Born, and Foreign Born Only, 1990

\begin{tabular}{|c|c|c|c|c|c|c|c|c|}
\hline \multirow[t]{3}{*}{ Variables } & \multicolumn{2}{|c|}{$\begin{array}{c}\text { Total Benefits } \\
\text { All }\end{array}$} & \multicolumn{2}{|c|}{$\begin{array}{c}\text { Claim Probability } \\
\text { All } \\
\end{array}$} & \multicolumn{2}{|c|}{$\begin{array}{c}\text { Total Benefits } \\
\text { Recipients }\end{array}$} & \multicolumn{2}{|c|}{$\begin{array}{c}\text { Weekly Benefits } \\
\text { Recipients }\end{array}$} \\
\hline & \multicolumn{3}{|c|}{ Foreign } & \multicolumn{2}{|l|}{ Foreign } & \multicolumn{2}{|c|}{ Foreign } & \multirow{2}{*}{$\begin{array}{c}\text { Foreign } \\
\text { Born } \\
\end{array}$} \\
\hline & Pooled & Born & Pooled & Born & Pooled & Born & Pooled & \\
\hline Education & -- & -- & -- & -- & + & + & + & + \\
\hline Experience & + & 0 & + & 0 & + & + & 0 & + \\
\hline Not Married & + & 0 & + & 0 & 0 & 0 & 0 & 0 \\
\hline Rural & + & + & + & + & -- & 0 & 0 & 0 \\
\hline South & -- & -- & -- & -- & 0 & 0 & 0 & 0 \\
\hline Agriculture & -- & + & -- & + & 0 & -- & 0 & 0 \\
\hline Foreign born & -- & (a) & -- & (a) & + & (a) & + & (a) \\
\hline Foreign/Agriculture & + & (a) & + & (a) & -- & (a) & 0 & (a) \\
\hline \multicolumn{9}{|l|}{ Year of Immigration } \\
\hline Pre-1950 & 0 & 0 & 0 & 0 & 0 & 0 & 0 & 0 \\
\hline $1950-1959$ & 0 & + & 0 & + & 0 & 0 & 0 & 0 \\
\hline 1960-1964 & 0 & + & 0 & + & + & 0 & + & + \\
\hline 1965-1969 & 0 & + & 0 & + & 0 & 0 & 0 & 0 \\
\hline $1970-1974$ & 0 & + & -- & + & 0 & 0 & 0 & 0 \\
\hline $1975-1979$ & -- & (a) & -- & (a) & 0 & (a) & 0 & (a) \\
\hline 1980-1981 & -- & -- & -- & -- & 0 & 0 & 0 & 0 \\
\hline $1982-1984$ & -- & -- & -- & -- & + & 0 & 0 & 0 \\
\hline 1985-1986 & -- & -- & -- & -- & 0 & 0 & 0 & + \\
\hline $1987-1990$ & -- & -- & -- & -- & + & 0 & 0 & 0 \\
\hline Naturalized Citizen & 0 & -- & 0 & -- & 0 & 0 & 0 & 0 \\
\hline Speaks English & 0 & -- & 0 & -- & 0 & + & 0 & 0 \\
\hline Constant & -- & -- & -- & -- & -- & 0 & -- & 0 \\
\hline
\end{tabular}


TABLE 7 continued

Notes: Only variables significant at the 5 percent level are signed; + means positive effect, -means negative effect; non-significant variables are marked with a "0".

Signs in the "Pooled" columns are derived from Tables 6, B-3, B-2, and B-4 respectively.

The "Foreign Born" variable is from column 2 in each table. All other variables are from column 4.

The signs in the "Foreign Born" columns are derived from Table B-5.

(a) Variable not entered. 


\section{IZA Discussion Papers}

\section{No. Author(s)}

31

C. M. Schmidt

32

S.- Å. Dahl

$\varnothing$. A. Nilsen

K. Vaage

33

A. Lindbeck

D. J. Snower

34

P. A. Puhani

D. A. Jaeger

A. Huff Stevens

36

C. Lauer

37

H. S. Buscher

C. Müller

M. E. Ward

P. J. Sloane
A. Lindbeck

D. J. Snower

40

S. M. Golder

T. Straubhaar

J. M. Orszag

D. J. Snower

42

D. S. Hamermesh

43

C. Belzil

J. Hansen

44

D. N. F. Bell

R. A. Hart

45

R. A. Hart

J. R. Malley

46
Title

Persistence and the German Unemployment Problem: Empirical Evidence on German Labor Market Flows

Work or Retirement? Exit Routes for Norwegian Elderly

Price Dynamics and Production Lags

Labour Mobility - An Adjustment Mechanism in Euroland?

Is Job Stability in the United States Falling? Reconciling Trends in the Current Population Survey and Panel Study of Income Dynamics

The Effects of European Economic and Monetary Union on Wage Behaviour

Exchange Rate Volatility Effects on the German Labour Market: A Survey of Recent Results and Extensions

Job Satisfaction within the Scottish Academic Profession

Multi-Task Learning and the Reorganization of Work

Empirical Findings on the Swiss Migration Experience

Anatomy of Policy Complementarities

The Changing Distribution of Job Satisfaction

Household Characteristics, Ability and Education:

Evidence from a Dynamic Expected Utility Model

Overtime Working in an Unregulated Labour Market

On the Cyclicality and Stability of Real Earnings 1

The Effects of Development on Migration: Theoretical Issues and New Empirical Evidence
Area Date

$1 / 7$ 2/99

$3 / 7$ 2/99 
Overtime Work and Overtime Compensation in

Unemployment and Labor-Market Reform: A

Ethnic German Migration After 1989 - Balance 1 and Perspectives

51 A. Barrett

P. J. O'Connell

Does Training Generally Work?

Self-Employment Decision of Immigrant

Entrepreneurs

\section{5 \\ L. Goerke}
A. Lindbeck

D. J. Snower

I. N. Gang

K. F. Zimmermann

T. Bauer

K. F. Zimmermann

D. J. DeVoretz

S. A. Laryea

60

C. Belzil

J. Hansen

61

R. Winkelmann

62
A. Thalmaier

63

M. Ward

64

M. Ward

65
H. Lehmann
J. Wadsworth
A. Acquisti

Value-added Tax versus Social Security Contributions

Centralized Bargaining and Reorganized Work: $\quad 1 / 5 \quad$ 9/99 Are they compatible?

Is Child like Parent?

Educational Attainment and Ethnic Origin

Occupational Mobility of Ethnic Migrants

Canadian Immigration Experience:

Any Lessons for Europe?

Subjective Discount Rates, Intergenerational

Bestimmungsgründe von Fehlzeiten: Welche

4



and the former Soviet Union to Germany: the Effects of Migrant Networks

Are Austrian Returns to Education Falling Over

Knowing What Works: The Case for Rigorous Program Evaluation

The Netherlands: Old Emigrants - Young Immigrant Country 
Tenures that Shook the World: Worker Turnover in Russia, Poland and Britain

Identification and Estimation of Causal Effects of

$\begin{array}{ll}92 & \text { R. E. Wright } \\ 93 & \text { M. Lechner }\end{array}$

P. Cahuc A. Zylberberg

P. Cahuc

A. Zylberberg

97

A. Barrett

L. Husted

H. S. Nielsen

M. Rosholm

N. Smith

102 B. van der Klaauw

J. C. van Ours
The Rate of Return to Private Schooling

An Evaluation of Public-Sector-Sponsored Continuous Vocational Training Programs in East Germany

An Evaluation of Public Employment Programmes in the East German State of Sachsen-Anhalt

Job Protection, Minimum Wage and Unemployment 3

Redundancy Payments, Incomplete Labor Contracts, Unemployment and Welfare 
Matching Model with Uncertainty -

An Extension of Mortensen and Pissarides (1994)

Job Tenure of Two Cohorts of Young German Men

107 J. C. van Ours G. Ridder

J. Boone

J. C. van Ours

109 G. J. van den Berg

$B$. van der Klaauw

110 D. DeVoretz

C. Werner

V. Sorm

K. Terrell

\section{Bellmann}

T. Schank

113 R. Euwals

114 G. Brunello

A. Medio

115 A. Cigno

F. C. Rosati

116

C. Belzil

119 A. Lindbeck D. J. Snower

120 P. T. Pereira P. S. Martins
Fast Track or Failure: A Study of the Completion Rates of Graduate Students in Economics

Modeling Financial Incentives to Get Unemployed Back to Work

Combining Micro and Macro Unemployment

Duration Data

A Theory of Social Forces and Immigrant Second

Sectoral Restructuring and Labor Mobility:

A Comparative Look at the Czech Republic

Innovations, Wages and Demand for

Heterogeneous Labour: New Evidence from a

Matched Employer-Employee Data-Set

Do Mandatory Pensions Decrease Household

Savings? Evidence for the Netherlands

An Explanation of International Differences in

Education and Workplace Training

Why do Indian Children Work, and is it Bad for

7

Them?

Unemployment Insurance and Subsequent Job

7

Duration: Job Matching vs. Unobserved

Heterogeneity

IAB Employment Subsample 1975-1995.

Opportunities for Analysis Provided by the

Anonymised Subsample

Improving Nurse Retention in the British National Health Service: The Impact of Job Satisfaction on Intentions to Quit

The Division of Labor and the Market for

Organizations

Does Education Reduce Wage Inequality? 
122 D. Munich

Returns to Human Capital under the Communist

The Income Portfolio of Immigrants in Germany -

Who Gains from Income Re-Distribution?

126 J. Fersterer

Smoking, Discount Rates, and Returns to

127 M. Karanassou

D. J. Snower

Characteristics of Unemployment Dynamics: The Chain Reaction Approach

Do Unemployment Insurance Recipients Actively Seek Work? Evidence From Randomized Trials in

O. Deschênes

Four U.S. States

129 B. R. Chiswick

The Employment, Unemployment and Unemployment Compensation Benefits of M. E. Hurst Immigrants 